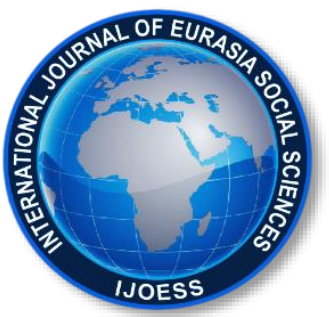

International Journal of Eurasia Social Sciences

Vol: 10, Issue: 37, pp. (1008-1020).

Scale Development

Received: 09.06.2019

Acepted: 25.09 .2019

\title{
VALIDITY AND RELIABILITY STUDY OF THE ATTITUDE TOWARDS FOREIGNERS SCALE ${ }^{1}$
}

\author{
Ersin YAĞAN \\ PhD Student, Ministry of National Education, Turkey, ersinyagan@gmail.com \\ ORCID: 0000-0003-3957-2762 \\ Belma AKŞiT \\ Prof. Dr. Maltepe University, belmaaksit@maltepe.edu.tr \\ ORCID: 0000-0002-9074-4251
}

\begin{abstract}
While it is obvious that the teachers who play an important role in the socialization process of the students are one of the most important actors in the adaptation of international students, there is a need for a measurement tool that demonstrates how they perceive the foreigners. Following this need, the "attitude towards foreigners scale" was developed to determine the teachers' perspectives on foreigners and validity and reliability studies were conducted. The study group of the research consists of 535 teachers working in Pendik District of Istanbul in the 2018-2019 academic year. In the process that started with 42 nominated items, the number of items was reduced to 29 after receiving expert opinions. Afterward, as a result of the EFA conducted by applying these 29 items to 290 teachers, the 29 -item draft scale was put into final form with the application of exploratory factor analysis as a single-factor structure with 18 items and this structure was tested using confirmatory factor analysis. The single-factor scale with 18-items explains 51.863 of the total variance. The Cronbach Alpha reliability coefficient of the scale was calculated as .962. Even though the scale was formed by taking the opinions of teachers into consideration, it may also be used for different groups.
\end{abstract}

Keywords: Prejudice, discrimination, scale development, attitudes of teachers

\footnotetext{
${ }^{1}$ This study is conducted within the scope of the doctoral thesis of the first author.
} 


\section{INTRODUCTION}

The impact of globalization or the turmoil in various regions of the world, voluntary or not, lead to the abolition of borders. The phenomenon of the immigrant, which was previously based on economic reasons mostly and faced by developed countries, is now on the agenda of all countries. The rapid increase in the number of foreigners in countries brings some structural and social concerns to the top of the agenda. Countries develop various policies so that their citizens and foreigners can live in harmony. When developing these policies, the concepts of prejudice and discrimination are among the prominent issues to be taken into consideration.

Prejudice, which is formed from the Latin words prae (pre) and judicium (judicium), is often considered as an attitude, and the object of attitude here is a social group (Hogg and Vaughan, 2017: 359). In daily life, prejudice usually means judgments about someone or something that are untimely or prematurely expressed or are immature. In other words, it refers to the formation of opinion and evaluation of a person or thing without having any direct experience with such a person or thing (Kirel et al., 2013: 53).

The prejudices of people consist of ideas, behaviors, and attitudes about other people and groups. Even though it is a neutral term, it refers to the attitude maintained towards an ethnic group in behavioral sciences studies (Guney, 2015: 152). While negative judgments about other people can be, for example, about issues that seem to be extremely insignificant, at times, they can emerge in deeply-rooted social issues, for example, towards different "races" or cultures. In the discipline of social psychology, which has been working on prejudices for most of the past century, the issue of prejudice has become increasingly significant (Kirel et al., 2013: 51).

Prejudice and discrimination constitute a major impediment in enlightenment; therefore, understanding their causes and consequences is one of the biggest challenges awaiting humanity (Hogg and Vaughan, 2017: 358). Prejudice, with limited opportunities, ranging from narrow horizons to physical violence and genocide, causes much of the pain and suffering in the world (Hogg and Vaughan, 2017: 358).

Social institutions (schools, government, media) can solidify prejudice through open policies such as racial discrimination in schools or by solidifying the status quo passively. Institutional support for prejudice is often indeliberate and processed without being noticed (Myers, 2017: 322-323).

Discrimination, which is closely related to prejudice, is the unequal treatment of different categories of people. Prejudice refers to attitudes; however, discrimination is a matter of the action. Like prejudice, discrimination can be positive (providing special benefits) or negative (creating obstacles) and is ranked from insensible to the extreme (Macionis, 2017: 365).

Pluralism is the state of being when people of all races and ethnicities are different but have equal social status. In other words, people who have social heritage and are different in appearance or share resources approximately equally. The U.S. is a pluralist country, where all people have equal status under the law. Besides, large cities comprise numerous ethnic villages where people proudly demonstrate the traditions of their 
immigrant ancestors. Pluralism promotes distinction without generating any disadvantages. Majorities usually separate minorities from themselves by ostracizing. Residential areas, schools, hospitals, occupations, even cemeteries, can be separate (Macionis, 2017: 366-367).

Sociology tries to bring in the people the ability to see the link between their own identities (individual stories) and major social and political developments. This ability, called sociological imagination, allows people to be able to historicize, understand and act as a social actor. Undoubtedly, 'understanding' is not the only antidote of discrimination. However, understanding the social processes is the beginning of educational, legal, architectural solutions, and so on concerning discrimination. Reducing discrimination between social groups and building an equal and peaceful society requires a much longer and more complex process (Cayir, 2018: 14). It is possible to suggest that bringing the accepted group identity into question, which is conveyed with the education system in connection with important social transformations and rising identity policies in the recent years in Turkey, determines the sense of "exclusion" and "victimization" witnessed in these groups and their perceptions and representations towards the "others" (Ustel and Caymaz, 2009: 53).

The biggest duty in enabling the people, who have had to emigrate from their countries of origin for very different reasons, to adapt to the countries they migrate to rests with the educational institutions of such countries. Therefore, it is of utmost importance to determine how the educational institutions, which have been tasked to ensure the socialization of the children of immigrant families, are prepared for such a situation. For this reason, a need to develop a valid and reliable Likert-type scale emerged, which can determine the perspectives of teachers, who work in educational institutions and play a key role in achieving the targets set by policymakers, towards foreigners. In the literature review, although it was seen that there are measurement tools in Turkey that measure the attitudes of teachers towards foreign students in schools (Saglam and Kanbur, 2017; Kilcan et al., 2017), there are no measurement tools that measure the attitudes of teachers towards all foreigners in the country. Thus, we aimed to develop a measurement tool in this study to determine the attitudes of teachers towards foreigners.

\section{METHOD}

\section{Research Design}

This study is a Likert-type scale development study and is conducted to develop the "Attitude Towards Foreigners Scale" and to form the validity and reliability study. Likert-type scales are used to determine the level of participation of an individual in a situation, event or opinion (Secer, 2015). Among the quantitative research designs, we preferred screening design to realize the purpose of the research. The screening-type study is a quantitative research procedure in which a small group of people (sample) is given a questionnaire or question form to identify the general trends in behaviors, attitudes, opinions, or characteristics of a large group of people (universe) (Creswell, 2017). The scale can measure the attitudes of teachers towards foreigners. 


\section{Study Group}

The study group of this study consists of 535 teachers working in Pendik District of Istanbul in the 2018-2019 academic year. The total number of teachers working in Pendik District in the same period is 7,644 . The study group constitutes $6.5 \%$ of the universe.

Table 1. Demographic Information of Factor Analysis Study Group

\begin{tabular}{llcc}
\hline \multicolumn{1}{c}{ Variables } & Groups & $\mathbf{f}$ & Percentage \\
\hline \multirow{2}{*}{ Gender } & Female & 183 & 63,1 \\
\hline Type of School & Male & 107 & 36,9 \\
& Elementary school & 95 & 32,8 \\
& Secondary school & 126 & 43,4 \\
& Religious Vocational & 59 & 20,3 \\
& Secondary School & & 3,4 \\
& Religious Vocational High & 10 & 100 \\
\hline \multirow{2}{*}{ Total } & School & 290 & \multirow{2}{*}{} \\
\hline
\end{tabular}

When we examine Table 1, we see that $183(63.1 \%)$ of the participants constituting the study group were female and $107(36.9 \%)$ were male teachers. 95 (32.8\%) of the teachers who participated in the study were working in Primary School, 126 (43.4\%) in Secondary School, 59 (20.3\%) in Religious Vocational Secondary School and 10 (3.4\%) in Religious Vocational High School.

Table 2. Demographic Information of Confirmatory Factor Analysis Study Group

\begin{tabular}{llcc}
\hline \multicolumn{1}{c}{ Variables } & Groups & $\mathbf{f}$ & Percentage \\
\hline \multirow{2}{*}{ Gender } & Female & 321 & 60.0 \\
& Male & 214 & 40.0 \\
\hline \multirow{2}{*}{ Type of School } & Elementary school & 129 & 24.1 \\
& Secondary school & 19.6 \\
& Religious Vocational & 105 & 12.3 \\
& Secondary School & 66 & 15.5 \\
& Anatolian High School & 83 & 11.0 \\
& Religious Vocational & 59 & 17.4 \\
\hline \multirow{2}{*}{ Total } & High School & 93 & 100 \\
\hline
\end{tabular}

When we examine Table 2, we see that 321 (60.0\%) of the participants constituting the study group were female, and $214(40.0 \%)$ were male teachers. $129(24.1 \%)$ of the teachers participating in the study were working in Primary School, 105 (19.6\%) in Secondary School, 66 (12.3\%) in Religious Vocational Secondary School, 83 (15.5\%) in Anatolian High School, 59 (11.0\%) in Religious Vocational High School and 93 (17.4\%) in Vocational High School.

\section{Scale Development Process}

The scale development process that is described in the introduction part of this study was followed during the scale development process. In this context, the researchers examined the studies conducted in Turkey and 
abroad on the phenomenon to be developed, which is frequently performed during the scale development process, and conducted interviews with teachers. The data obtained from these interviews were used while developing the scale items. The researchers wrote 42 items based on these data. Afterwards, the number of items was clarified as 29 as a result of the evaluations of existing items and additions and omissions of items conducted with the help of two teachers from the departments of Turkish, Psychological Guiding and Counseling (PGC), Foreign Language and Classroom Teaching and two instructors who have expertise in Sociology and Education Administration and Inspection. The scale answers were developed in Likert type, and the answers were formed as "Completely Agree (5), Agree (4), Do Not Have An Opinion (3), Disagree (2) and Completely Disagree (1).

In this study, exploratory factor analysis (EFA) was conducted first, and afterwards the revealed structure was controlled by confirmatory factor analysis (CFA). Detailed information on factor analysis is presented in detail in the findings and discussion sections of this study.

\section{Data Collection}

First of all, the researchers in person applied the $350 \mathrm{draft}$ scale forms with 29 items that they prepared to collect data for Factor Analysis by making necessary explanations to the teachers. 90 of the draft forms that were distributed were not included in the analysis for the reason that some of them were not returned back and some were filled incompletely or incorrectly. Factor analysis was conducted with data obtained from 290 teachers. It is suggested that 5 or 10 times the number of items of study group/sample size recommended for factor analysis would be sufficient (Tavsancil, 2006; Nunnally, 1978). The data obtained were collected during the month of April 2019. The data obtained as a result of the scale applied to 290 teachers were evaluated by EFA and the 18-item scale, which was put into final form as a result of the omission of 11 items, was applied to 535 teachers in total and CFA was performed with these data. Before starting the data collection process, necessary permissions were obtained from Istanbul Provincial Directorate of National Education. In schools where the scale application would be performed, permissions from school administrations were obtained, teachers were informed about the scale and, afterward, the scale was applied voluntarily.

\section{Data Analysis}

Descriptive values of the data were examined, and EFA and CFA were performed for the validity of the scale to determine whether the data were suitable for analysis. Item-total and item-remainder correlation analysis, independent groups t-test and Cronbach Alpha analysis were used within the context of reliability study. EFA and reliability analyses were performed by utilizing the SPSS program and CFA by the AMOS program.

\section{FINDINGS}

\section{Findings on Validity Studies}

The data set was examined before conducting the factor analysis. Descriptive values of the data set are provided in Table 3. 
Table 3. Descriptive Statistics

\begin{tabular}{lc}
\hline Average & 85.6586 \\
Median & 85.0000 \\
Variance & 458.606 \\
Std. Deviation & 21.41509 \\
Minimum & 33.00 \\
Maximum & 141.00 \\
Range & 108.00 \\
Skewness & .101 \\
Kurtosis & -.391 \\
Kolmogorov-Smirnov (df: $290 ; \mathrm{p} \geq, 05)$ & .200 \\
\hline
\end{tabular}

When Table 3 is examined, it is agreed that the fact that the skewness (.101) and kurtosis (.391) values of the data set are within \pm 1 values and that the Kolmogorov-Smirnov ( $d f=290 ; p \geq .05$ ) value is insignificant (Cokluk et al,. 2012) shows the normal distribution of the data set. In this study, it was decided that the data set was suitable for factor analysis (Tatlidil, 2002) for the reason that Kaiser-Meyer-Olkin value was 0.951 and Bartlett Sphericity Test value was $5446,795(p<.000)$.

It was determined that the data was suitable for factor analysis. Factor analysis was conducted by starting with the principal components analysis. The eigenvalues obtained from the first analysis conducted and the variances described are given in Table 4.

Table 4. Eigenvalues from Draft Scale in the First Analysis and Variances Described

\begin{tabular}{cccc}
\hline Factor & Eigenvalue & Variance & Cumulative \\
\hline $\mathbf{1}$ & 12.911 & 44.521 & 44.521 \\
\hline $\mathbf{2}$ & 2.296 & 7.917 & 52.438 \\
\hline $\mathbf{3}$ & 1.395 & 4.811 & 57.249 \\
\hline $\mathbf{4}$ & 1.137 & 3.922 & 61.171 \\
\hline $\mathbf{5}$ & 1.082 & 3.732 & 64.903 \\
\hline
\end{tabular}

Table 4 shows that the first factor has greater eigenvalue and variance when compared to other factors. Of the total variance of $64.903 \%$, the first factor describes the $44.521 \%$, the second factor $7.917 \%$, the third factor $4.811 \%$, the fourth factor $3.922 \%$, and the fifth factor $3.732 \%$. It is seen that the first factor includes other factors. Moreover, the Scree Plot provided in Figure 1 was examined to provide proof about whether the items would be distributed to factors or not. 


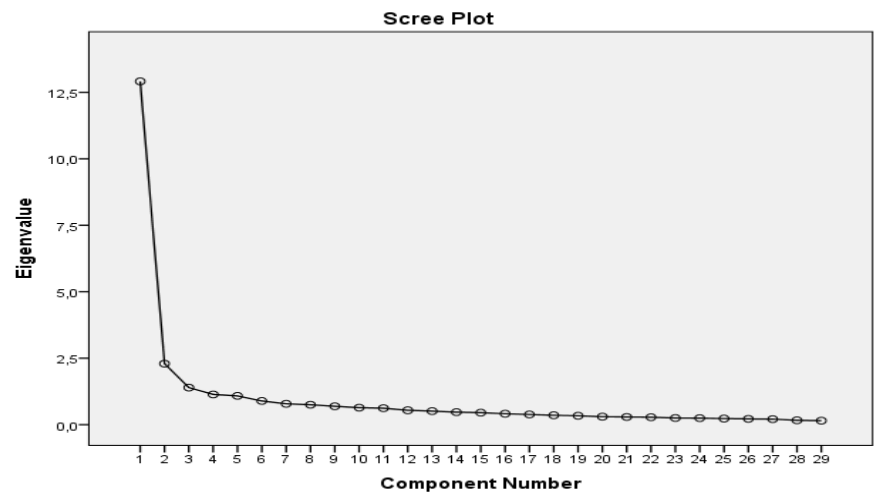

Figure 1. Scree Plot for 29-Item Draft Scale

When we examine the Scree Plot provided in Figure 1, we see that the scale could have a single-factor structure. For this reason, rotation analysis was not conducted. Item loads are provided in Table 6.

Table 5. Eigenvalues from Draft Scale in the Second Analysis and Variances Described

\begin{tabular}{cccc}
\hline Factor & Eigenvalue & Variance & Cumulative \\
\hline $\mathbf{1}$ & 11.410 & 51.863 & 51.863 \\
\hline $\mathbf{2}$ & 1.853 & 8.421 & 60.284 \\
\hline
\end{tabular}

Table 5 shows that the first factor has much greater eigenvalue and variance when compared to the other factor. Of the total variance of $60.284 \%$, the first factor describes the $51.86 \%$, and the second factor $8.42 \%$. It is seen that the first factor includes the other factor. Moreover, the Scree Plot provided in Figure 2 was examined to provide proof about whether the items would be distributed to factors or not.

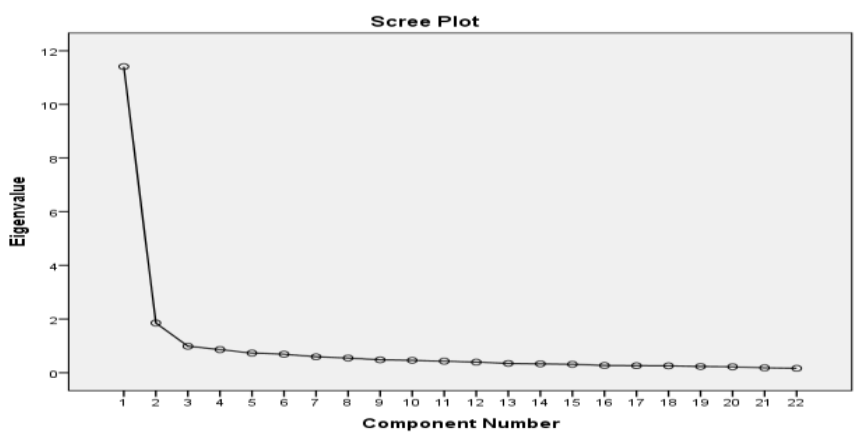

Figure 2. Scree Plot for 18-Item Scale

When we examine the Scree Plot provided in Figure 2, we see that the scale could have a single-factor structure. For this reason, rotation analysis was not conducted. The factor loads of items are provided in Table 5.

Table 6. Factor Loads of the Scale

\begin{tabular}{cclcc}
\hline $\begin{array}{c}\text { Item } \\
\text { order }\end{array}$ & $\begin{array}{c}\text { Item } \\
\text { No. }\end{array}$ & \multicolumn{1}{c}{ Item } & $\begin{array}{r}\text { Item } \\
\text { Load }\end{array}$ \\
\hline $\mathbf{1}$ & M1 & The presence of foreigners in my country makes me uncomfortable. & $\mathbf{. 8 0 9}$ \\
\hline $\mathbf{2}$ & M2 & $\begin{array}{l}\text { I think that the increase in the number of foreigners increases the problems in my } \\
\text { country. }\end{array}$ & $\mathbf{. 7 9 0}$ \\
\hline $\mathbf{3}$ & M5 & I want foreigners to be taken out of my country as soon as possible. & $\mathbf{. 8 1 3}$ \\
\hline
\end{tabular}




\begin{tabular}{|c|c|c|c|}
\hline 4 & M6 & $\begin{array}{l}\text { I sometimes feel like a second class citizen in my country in relation to the } \\
\text { services and opportunities offered to foreigners. }\end{array}$ & .759 \\
\hline 5 & M7 & The increase in the number of foreigners affects our lifestyle negatively. & .846 \\
\hline 6 & M9 & I presume that foreigners will cause much bigger problems in the future. & .849 \\
\hline 7 & M10 & Foreigners disturb the peaceful atmosphere in my country. & .880 \\
\hline 8 & M12 & Foreigners destroy the Turkish family structure. & .662 \\
\hline 9 & M15 & $\begin{array}{l}\text { I am uncomfortable with the improvement of the socio-economic conditions of } \\
\text { foreigners. }\end{array}$ & .634 \\
\hline 10 & M16 & $\begin{array}{l}\text { The increase in the number of foreigners poses a danger to the future of my } \\
\text { children. }\end{array}$ & .833 \\
\hline 11 & M18 & I think the opportunities provided for foreigners are too much. & .775 \\
\hline 12 & M20 & Foreigners cause infectious diseases in my country to increase. & .703 \\
\hline 13 & M22 & $\begin{array}{l}\text { Foreigners cause security incidents (theft, smuggling, prostitution, etc.) in my } \\
\text { country to increase. }\end{array}$ & .791 \\
\hline 14 & M24 & $\begin{array}{l}\text { Foreigners should be kept in certain areas or camps and should not be allowed to } \\
\text { interact with the local community. }\end{array}$ & .614 \\
\hline 15 & $\mathrm{M} 25$ & $\begin{array}{l}\text { The increase in the number of foreigners poses a serious threat to the integrity of } \\
\text { my country in the future. }\end{array}$ & .820 \\
\hline 16 & M27 & I would be uncomfortable with the foreigners being naturalized. & .668 \\
\hline 17 & M28 & I think that the foreigners in my country enrich our lifestyle. & .612 \\
\hline 18 & M29 & I can dream of a common future in harmony with foreigners in my country. & .695 \\
\hline \multicolumn{3}{|c|}{ Total variance } & 51,863 \\
\hline
\end{tabular}

As seen in Table 6, item loads of the scale vary between 0.612 and 0.880 . Confirmatory factor analysis was conducted for the validity of the single-factor structure (See Figure 3 ).

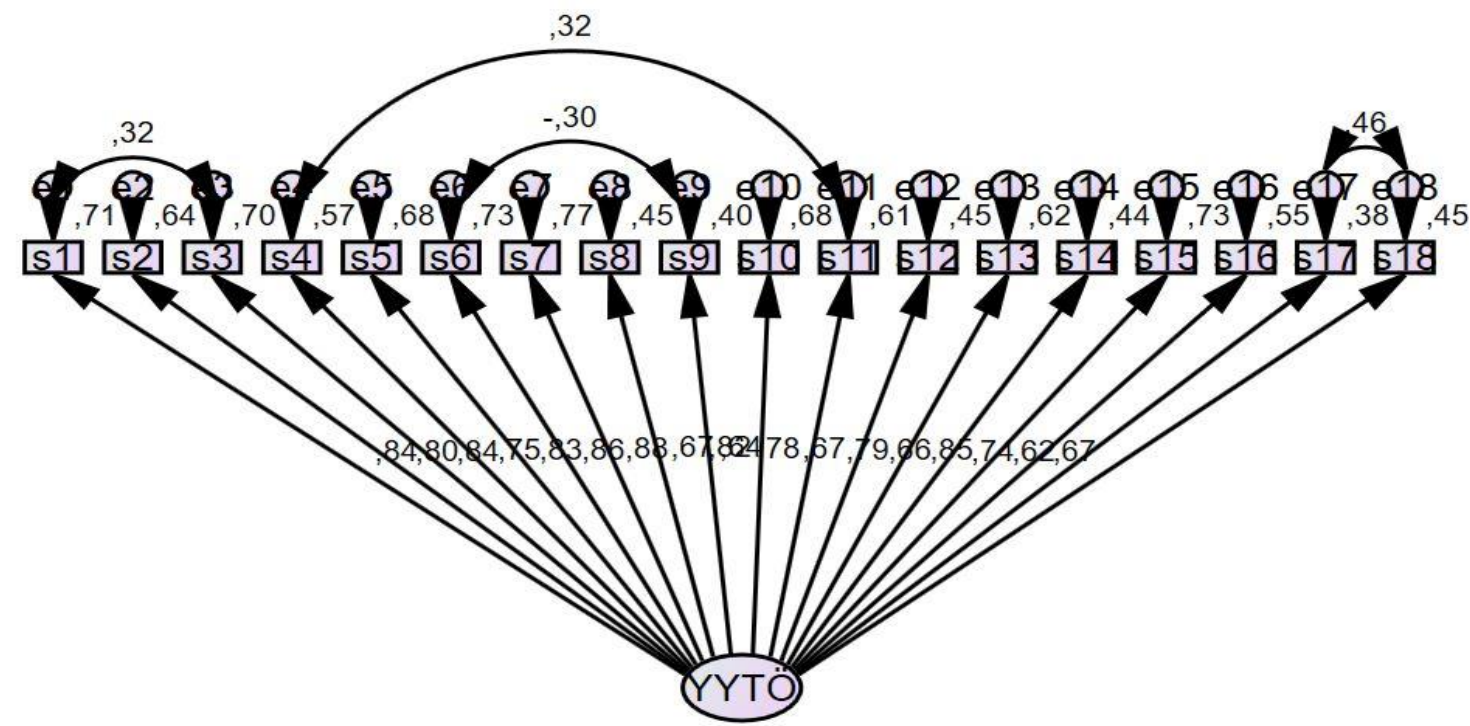

Figure 3. Attitude Towards Foreigners Scale First Level Confirmatory Factor Analysis

In Figure 3, the fit index values were examined to reach a conclusion about the accuracy of the structure tested with the confirmatory factor analysis. The values of the ratio of chi-square to the degree of freedom 
$(x 2 / d f=3.613), \operatorname{GFI}(, 862), \operatorname{AGFI}(, 830), \operatorname{CFI}(, 925)$, RMR $(, 089)$ suggested that the scale had an acceptable concordance (Kline, 2011).

\section{Findings on Reliability Studies}

The Cronbach Alpha reliability coefficient, which was examined to provide proof for the reliability of the scale, is provided in Table 7.

Table 7. Cronbach Alpha Reliability Coefficient of Attitude Towards Foreigners Scale

\begin{tabular}{lc}
\hline General & Cronbach-Alpha Internal Consistency Coefficients \\
\hline
\end{tabular}

As seen in Table 7, the Cronbach Alpha reliability coefficient of the scale is 0.962 . Table 8 provides the values obtained in item-total, and item-remainder correlation analyzes to present an argument for whether or not items are consistent and necessary for the scale.

Table 8. Item-Total and Item-Remainder Correlation Analysis Results

\begin{tabular}{ccc}
\hline Item & Item-total & Item-remainder \\
\hline $\mathbf{1}$ & .855 & .857 \\
$\mathbf{2}$ & .793 & .796 \\
$\mathbf{3}$ & .858 & .858 \\
$\mathbf{4}$ & .777 & .783 \\
$\mathbf{5}$ & .823 & .826 \\
$\mathbf{6}$ & .838 & .840 \\
$\mathbf{7}$ & .873 & .876 \\
$\mathbf{8}$ & .696 & .698 \\
$\mathbf{9}$ & .669 & .670 \\
$\mathbf{1 0}$ & .830 & .831 \\
$\mathbf{1 1}$ & .806 & .809 \\
$\mathbf{1 2}$ & .687 & .693 \\
$\mathbf{1 3}$ & .792 & .794 \\
$\mathbf{1 4}$ & .701 & .701 \\
15 & .858 & .859 \\
$\mathbf{1 6}$ & .770 & .766 \\
$\mathbf{1 7}$ & .673 & .657 \\
18 & .716 & .680 \\
\hline
\end{tabular}

$* p<.01$

In Table 8, it is seen that item-total and item-remainder correlation coefficients were significant $(p<.01)$, itemtotal correlation coefficients were between $r=.669$ and $r=.873$, and item-remainder correlation coefficients were $r=.657$ and $r=.876$.

To provide proof for the success of the items in distinguishing the low and high groups, the study group was divided into low and high groups of $27 \%$ each; scores were sorted from low to high and independent group t-test analysis was conducted. 27\% low and high independent group t-test results are provided in Table 9. 
Table 9. Independent Samples t-Test Results

\begin{tabular}{|c|c|c|c|c|c|c|c|}
\hline Item & Group & $\mathbf{N}$ & Mean & ss & $T$ & sd & $p$ \\
\hline \multirow{2}{*}{1} & Low & 144 & 1.500 & .7096 & \multirow{2}{*}{-36.690} & \multirow{2}{*}{286} & \multirow{2}{*}{.000} \\
\hline & High & 144 & 4.361 & .6101 & & & \\
\hline \multirow{2}{*}{2} & Low & 144 & 1.222 & .4172 & \multirow{2}{*}{-22.587} & \multirow{2}{*}{286} & \multirow{2}{*}{.000} \\
\hline & High & 144 & 3.486 & 1.1281 & & & \\
\hline \multirow{2}{*}{3} & Low & 144 & 1.576 & .7153 & \multirow{2}{*}{-35.942} & \multirow{2}{*}{286} & \multirow{2}{*}{.000} \\
\hline & High & 144 & 4.333 & .5794 & & & \\
\hline \multirow{2}{*}{4} & Low & 144 & 1.514 & .7094 & \multirow{2}{*}{-28.498} & \multirow{2}{*}{286} & \multirow{2}{*}{.000} \\
\hline & High & 144 & 4.201 & .8817 & & & \\
\hline \multirow{2}{*}{5} & Low & 144 & 1.444 & .6561 & \multirow{2}{*}{-25.527} & \multirow{2}{*}{286} & \multirow{2}{*}{.000} \\
\hline & High & 144 & 3.854 & .9234 & & & \\
\hline \multirow{2}{*}{6} & Low & 144 & 1.132 & .3596 & \multirow{2}{*}{-29.277} & \multirow{2}{*}{286} & \multirow{2}{*}{.000} \\
\hline & High & 144 & 3.618 & .9534 & & & \\
\hline \multirow{2}{*}{7} & Low & 144 & 1.479 & .5909 & \multirow{2}{*}{-34.137} & 286 & 000 \\
\hline & High & 144 & 3.972 & .6472 & & 286 & .000 \\
\hline 8 & Low & 144 & 1.931 & .9941 & 18661 & 286 & 000 \\
\hline 8 & High & 144 & 3.903 & .7873 & -18.664 & $\angle 80$ & .000 \\
\hline 9 & Low & 144 & 2.146 & 1.1525 & -17773 & 286 & 000 \\
\hline & High & 144 & 4.153 & .7127 & & & \\
\hline 10 & Low & 144 & 1.417 & .6531 & 013 72- & 286 & 000 \\
\hline 10 & High & 144 & 3.896 & .8422 & -27.913 & 280 & .000 \\
\hline 11 & Low & 144 & 1.319 & .4969 & ח265 & 286 & 000 \\
\hline & High & 144 & 3.667 & .9387 & $-20.5<0$ & 280 & .000 \\
\hline 12 & Low & 144 & 1.583 & .7619 & -17698 & 286 & 000 \\
\hline 12 & High & 144 & 3.403 & .9703 & -17.090 & 200 & .000 \\
\hline 13 & Low & 144 & 1.389 & .5434 & -25305 & 286 & 000 \\
\hline & High & 144 & 3.521 & .8525 & & & \\
\hline 14 & Low & 144 & 1.597 & .9775 & -20 627 & 286 & 000 \\
\hline 14 & High & 144 & 3.938 & .9477 & -20.021 & 200 & .000 \\
\hline 15 & Low & 144 & 1.201 & .5743 & -34882 & 286 & 000 \\
\hline & High & 144 & 3.854 & .7093 & & & \\
\hline 16 & Low & 144 & 1.167 & .5289 & 23215 & 286 & 000 \\
\hline 10 & High & 144 & 3.521 & 1.0901 & -23.315 & 286 & .000 \\
\hline 17 & Low & 144 & 1.701 & .9829 & -17323 & 286 & 000 \\
\hline & High & 144 & 3.625 & .8997 & $-17.5<3$ & 200 & .000 \\
\hline 18 & Low & 144 & 1.486 & .8609 & & 286 & 000 \\
\hline 10 & High & 144 & 3.611 & .9015 & -20.451 & 200 & .000 \\
\hline Total & Low & 144 & 1.4892 & 1.434 & -55.949 & 286 & .000 \\
\hline score & High & 144 & 3.8287 & 5.903 & -55.949 & 286 & .000 \\
\hline
\end{tabular}

When we examine Table 9, we see that there is a significant difference between the low and high groups $(p<.01)$; the items distinguish the low and high groups of $27 \%$ each, and this significant difference is in favor of the high group. In other words, the low and high groups perceive the items differently.

\section{CONCLUSION and DISCUSSION}

In this study, we aimed to develop a scale to determine the attitudes of teachers towards foreigners living in Turkey today. To serve this purpose, we conducted interviews with teachers working in public schools and 
formed the pool of items. After obtaining expert opinions, we conducted the validity and reliability studies. As a result of the studies and analyses conducted, the scale was found to be valid and reliable.

The scale was prepared by taking the opinions of the teachers and can be applied to other occupational groups or adults in future studies to contribute to the validity and reliability level.

\section{REFERENCES}

Creswell, J. W. (2017). Educational surveys: Planning, conducting and evaluating quantitative and qualitative research (Translation Editor: Eksi, H.). Istanbul: Edam Publishing

Cayir, K. (2018). Discrimination in the context of intergroup relations. Discrimination, Multidimensional Approaches, 5-15.

Cokluk, O., Sekercioglu, G., \& Buyukozturk, S. (2012). Multivariate statistics for social sciences: SPSS and LISREL applications (Vol. 2). Ankara: Pegem Academy.

Guney, S. (2015). Social psychology. Istanbul: Nobel Publishing.

Hogg, M. A., Vaughan, G.M. (2017). Social psychology. (Translated by I. Yildiz, A, Gelmez) Ankara: Utopya Publishing

Kilcan, B., Cepni, O., \& Kilinc, A. C. (2017). Development of the Attitude Towards Refugee Students Scale. Journal of Human Sciences, 14(2), 1045-1057.

Kirel, C., Kayaoglu, A. and Gokdag, R. (2013). Social psychology - II. Eskisehir: Anatolian University Publications.

Kline, R.B. (2011) Principles and Practice of Structural Equation Modeling. Guilford Press, New York.

Macionis, J. J. (2017). Sociology. (Translated by V. Akan) Istanbul: Nobel Publishing.

Myers, D.G. (2017). Social psychology. (Translated by S. Akfirat) Istanbul: Nobel Publishing.

Nunnally, J. C. (1978). Psychometric theory. New York: McGraw Hill.

Saglam, H. I. and Ilksen Kanbur, N.(2017). Research on the Attitudes of Classroom Teachers towards Refugee Students in Terms of Various Variables. Sakarya University Journal of Education, 7(2), 310-323.

Secer, I. (2015). Practical data analysis with SPSS and LISREL: Analysis and reporting. Ani Publishing.

Tatlidil, H. (2002). Applied multivariate statistical analysis. Ankara: Ziraat Printing

Tavsancil, E. (2006). Measuring the attitudes and data analysis with SPSS. (3rd Edition). Ankara: Nobel.

Ustel, F., Caymaz, B. (2009). The elite and the social distance. Istanbul Bilgi University. 
APPENDIX 1: Attitude Towards Foreigners Scale

* The foreign word in the survey is used for the refugees, asylum-seekers and guests under temporary protection who had been forced to immigrate to Turkey for various reasons.

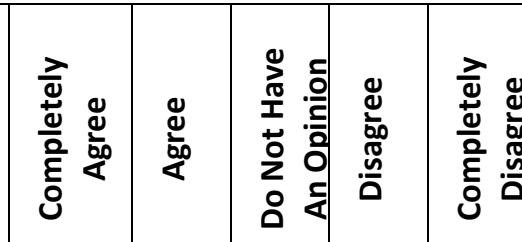

1. The presence of foreigners in my country makes me uncomfortable.

2. I think that the increase in the number of foreigners increases the problems in my country.

3. I want foreigners to be taken out of my country as soon as possible.

4. I sometimes feel like a second class citizen in my country in relation to the services and opportunities offered to foreigners.

5. The increase in the number of foreigners affects our lifestyle negatively.

6. I presume that foreigners will cause much bigger problems in the future.

7. Foreigners disturb the peaceful atmosphere in my country.

8. Foreigners destroy the Turkish family structure.

9. I am uncomfortable with the improvement of the socio-economic conditions of foreigners.

10. The increase in the number of foreigners poses a danger to the future of my children.

11. I think the opportunities provided for foreigners are too much.

12. Foreigners cause infectious diseases in my country to increase.

13. Foreigners cause security incidents (theft, smuggling, prostitution, etc.) in my country to increase.

14. Foreigners should be kept in certain areas or camps and should not be allowed to interact with the local community.

15. The increase in the number of foreigners poses a serious threat to the integrity of my country in the future.

16. I would be uncomfortable with the foreigners being naturalized.

17. I think that the foreigners in my country enrich our lifestyle.

18. I can dream of a common future in harmony with foreigners in my country.

Note: The study can be used for research purposes without permission, provided that reference is made. 
EK 1: Yabancılara Yönelik Tutum Ölçeği

* Ankette kullanılan yabancı kavramı Türkiye'ye çeşitli sebeplerle göç etmek zorunda kalmış mülteciler, sığınmacılar ve geçici koruma kapsamındaki misafirler için kullanılmaktadır.

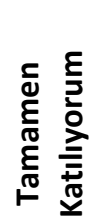

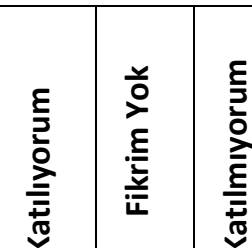

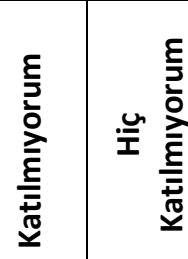

1. Ülkemdeki yabancıların varlığı beni huzursuz ediyor.

2. Yabancıların sayısının artmasının ülkemdeki sorunları da artırdığını düşünüyorum.

3. Yabancıların ülkemden bir an önce çıkarılmasını istiyorum.

4. Yabancılara sunulan hizmet ve imkânlar karşısında bazen kendimi ülkemde ikinci sınıf vatandaş gibi hissediyorum.

5. Yabancıların sayısının artması yaşam tarzımızı olumsuz etkilemektedir.

6. Yabancıların gelecekte çok daha büyük sorunlara sebep olacaklarını tahmin ediyorum.

7. Yabancılar ülkemdeki huzur ortamını bozmaktadır.

8. Yabancılar Türk aile yapısına zarar veriyor.

9. Yabancıların sosyo-ekonomik anlamda koşullarının iyileşmesinden rahatsızlık duyuyorum.

10. Yabancı sayısındaki artış, çocuklarımın geleceği açısından tehlike oluşturuyor.

11. Yabancılara verilen imkânların çok fazla olduğunu düşünüyorum.

12. Yabancılar ülkemdeki bulaşıcı hastalıkların artmasına sebep olmaktadır.

13. Yabancılar ülkemdeki asayiş olaylarının (hırsızlık, kaçakçılık, fuhuş gibi) artmasına sebep oluyor.

14. Yabancılar belirli bölgelerde - kamplarda barındırılmalı, yerel halkın arasına karışmaları engellenmelidir.

15. Yabancı sayısının artması gelecekte ülkemin bütünlüğü için ciddi bir tehdit oluşturuyor.

16. Yabancılara vatandaşlık verilmesinden rahatsız olurum.

17. Ülkemde bulunan yabancıların yaşam tarzı açısından bize zenginlik kattığını düşünüyorum.

18. Ülkemdeki yabancılarla uyum içinde ortak bir gelecek hayali kurabiliyorum.

Not: Referans gösterilmek koşuluyla izin alınmadan araştırma amaçlı kullanılabilir. 